Rozana Oliveira Gonçalves'

Wendell Vilas Boas Santos ${ }^{2}$

Manoel Sarno ${ }^{3}$

Bruno Antonio Veloso Cerquera ${ }^{4}$

MarlLDA SOUZa Gonçalves ${ }^{2}$

Olivia LuCia Nunes COSTA ${ }^{3}$

Original Article

Keywords

Abortion, habitual

Chromosome aberrations Translocation, genetic

Pregnancy trimester, first

Palavras-chave

Aborto habitual

Aberrações cromossômicas

Translocação genética

Primeiro trimestre da gravidez

\title{
Chromosomal abnormalities in couples with recurrent first trimester abortions
}

\author{
Alterações cromossômicas em casais com aborto recorrente \\ de primeiro trimestre
}

Abstract

PURPOSE: To investigate the prevalence of chromosomal abnormalities in couples with two or more recurrent first trimester miscarriages of unknown cause. METHODS: The study was conducted on 151 women and 94 partners who had an obstetrical history of two or more consecutive first trimester abortions (1-12 weeks of gestation). The controls were 100 healthy women without a history of pregnancy loss. Chromosomal analysis was performed on peripheral blood lymphocytes cultured for 72 hours, using Trypsin-Giemsa (GTG) banding. In all cases, at least 30 metaphases were analyzed and 2 karyotypes were prepared, using light microscopy. The statistical analysis was performed using the Student ttest for normally distributed data and the Mann-Whitney test for non-parametric data. The Kruskal-Wallis test or Analysis of Variance was used to compare the mean values between three or more groups. The software used was Statistical Package for the Social Sciences (SPSS), version 17.0. RESULTS: The frequency of chromosomal abnormalities in women with recurrent miscarriages was $7.3 \%$, including $4.7 \%$ with $\mathrm{X}$-chromosome mosaicism, $2 \%$ with reciprocal translocations and $0.6 \%$ with Robertsonian translocations. A total of $2.1 \%$ of the partners of women with recurrent miscarriages had chromosomal abnormalities, including $1 \%$ with X-chromosome mosaicism and $1 \%$ with inversions. Among the controls, $1 \%$ had mosaicism. CONCLUSION: An association between chromosomal abnormalities and recurrent miscarriage in the first trimester of pregnancy $(\mathrm{OR}=7.7 ; 95 \% \mathrm{Cl} 1.2-170.5)$ was observed in the present study. Etiologic identification of genetic factors represents important clinical information for genetic counseling and orientation of the couple about the risk for future pregnancies and decreases the number of investigations needed to elucidate the possible causes of miscarriages.

\section{Resumo}

OBJETIVO: Determinar a prevalência de alterações cromossômicas em casais com dois ou mais abortos recorrentes do primeiro trimestre, sem causa definida. MÉTODOS: Foram incluídas 151 mulheres e 94 parceiros com história obstétrica de 2 ou mais abortos consecutivos de $1^{\circ}$ trimestre (1-12 semanas de gestação). Os controles foram 100 mulheres saudáveis, sem histórico de perda da gravidez. A análise cromossômica foi realizada em linfócitos de sangue periférico, cultivados 72 horas e tratados com a técnica Tripsina-Giemsa (GTG banda). Em todos os casos, foram analisadas 30 metáfases e montados 2 cariótipos, sendo utilizada microscopia de luz. A análise estatística foi realizada por meio do teste t de Student para dados com distribuição normal e o teste Mann-Whitney para os dados não paramétricos. Foi usado o teste de KruskalWallis ou Análise de Variância para comparação dos valores médios entre três ou mais grupos. O software utilizado foi o Statistical Package for the Social Sciences (SPSS), versão 17.0. RESULTADOS: A frequência de alterações cromossômicas das mulheres com aborto recorrente foi de 7,3\%, incluindo 4,7\% com mosaicismo do cromossomo X, $2 \%$ com translocações recíprocas e 0,6\% com translocações Robertsonianas. No total, 2,1\% dos parceiros das mulheres com abortos recorrentes tinham anormalidades cromossômicas, sendo 1\% com mosaicismo do cromossomo Xe 1\% com inversões. Entre os controles, 1\% apresentou mosaicismo. CONCLUSÃO: No presente estudo, foi observada associação entre alterações cromossômicas e aborto recorrente no primeiro trimestre da gestação $\mid O R=7,7 ; 1 C 95 \%$ 1,2-170,5). A identificação etiológica de fatores genéticos é uma informação clínica importante para o aconselhamento genético e orientação do casal quanto ao risco para gestações futuras, bem como diminui o número de investigações para elucidar as possíveis causas dos abortamentos.

Correspondence

Rozana Oliveira Goncalves Rua Waldemar Falcão, 121 - Candeal Zip code: $40296-710$ Salvador (BA), Brazil

Received on

$11 / 21 / 2013$
Departamento de Ginecologia e Obstetrícia, Universidade Federal da Bahia - UFBA - Salvador (BA), Brazil.

'Programa de Pós-Graduação, Centro de Pesquisas Gonçalo Moniz, Fundação Oswaldo Cruz - FlOCRUZ - Salvador (BA), Brazil.

${ }^{2}$ Centro de Pesquisas Gonçalo Moniz, Fundação Oswaldo Cruz - FlOCRUZ - Salvador (BA), Brazil.

${ }^{3}$ Departamento de Ginecologia e Obstetrícia, Universidade Federal da Bahia - UFBA - Salvador (BA), Brazil.

${ }^{4}$ Universidade Estadual de Santa Cruz - Ihéus (BA), Brazil.

Conflict of interests: none. 


\section{Introduction}

Recurrent miscarriage is usually defined as the occurrence of 3 or more consecutive pregnancy losses before 20 weeks of gestation or the loss of three consecutive fetuses of less than $500 \mathrm{~g}$ in weight $\mathrm{t}^{1,2}$. Recurrent spontaneous abortion (RSA) is a condition that occurs in $2-5 \%$ of couples ${ }^{3,4}$.

Abortion is considered a multifactorial problem, with different causes involved in its etiology, including environmental, genetic, anatomical, endocrine, immunological thrombophilic and infectious diseases ${ }^{4,5}$.

It has been reported that $50 \%$ of spontaneously aborted fetuses have chromosomal abnormalities ${ }^{6}$. The majority of such abnormalities are due to chromosomal non-disjunction or mutation. However, unbalanced translocations account for approximately $1 \%$ of spontaneous miscarriages. In such cases, a parental carrier of a structural chromosome rearrangement, most commonly a reciprocal or Robertsonian translocation, has often been identified ${ }^{7,8}$. In approximately $3-5 \%$ of couples with recurrent miscarriage, one of the partners is affected by a chromosomal translocation, as opposed to $0.2 \%$ in the normal population. This may repeatedly produce an unbalanced gamete, resulting in the recurrence of spontaneous miscarriage ${ }^{9-11}$.

\section{Methods}

One case-control study was conducted to investigate the association between idiopathic recurrent miscarriages and chromosomal abnormalities. Miscarriage diagnosis was based on clinical history and clinical examination. The study population included 151 women and 94 partners who had an obstetrical history of 2 or more consecutive first-trimester abortions (1-12 gestation weeks) who completed a systematic examination at routine consultation to miscarriage, such as tests for abnormal chromosomes, endocrine abnormalities and uterine anomalies. Study subjects were recruited between January 2011 and July 2012, from four health centers in Salvador, Bahia, Brazil, which operate a comprehensive medical and health program for pregnant women. We excluded women with two miscarriages with different partners, with a living children, besides those who were over 40 years of age and suffering from a disease associated with gestational failure, such as hypertension, infections, uterine anomalies, antiphospholipid syndrome, inherited thrombophilia, hypothyroidism and diabetes mellitus. The controls were 100 healthy women who gave birth at the Maternity Climério de Oliveira (MCO), with no history of abortion, aged up to 40 years and with at least one living child. They were selected by review of medical records and interview.

A questionnaire was administered to all subjects to collect demographic characteristics, lifestyle (consumption of alcohol, coffee, cigarettes and drugs), family history and work environment data. All participating subjects personally provided their consent to participate in the study.

\section{Chromosome preparations}

Chromosomes from cultured peripheral blood lymphocytes were analyzed using Trypsin-Giemsa (GTG) banding: $5 \mathrm{~mL}$ of peripheric blood samples were taken to heparinized injectors for karyotyping. Peripheral blood lymphocytes were stimulated with fitohemaglutinina $(0.1 \mathrm{~mL})$ and cultured for $72 \mathrm{~h}$ at $37^{\circ} \mathrm{C}$, in RPMI 1640 medium. Colchicine was added at $16 \mu \mathrm{g} / \mathrm{mL}$ to the cultures $1 \mathrm{~h}$ before harvesting. Slides were prepared after hypotonic treatment of the cells with $\mathrm{KCl}(0.075 \mathrm{M})$ followed by fixation in methanol/glacial acetic acid $(3 / 1 \mathrm{vol} / \mathrm{vol})$. A concentrated suspension of the cells was dropped on slides, which were aged in the incubator at $37^{\circ} \mathrm{C}$ for 3 days and then stained with the G-banding technique. In all cases, at least 30 metaphases were analyzed and 2 karyotypes were prepared, using light microscopy. In cases of suspected mosaicism, 50 cells were counted. All of the metaphases were examined for gross structural or numerical cytogenetic anomalies.

\section{Statistical analysis}

The distribution of quantitative variables was determined using the Kolmogorov-Smirnov test. The means of the quantitative variables between the two groups were compared using the Student $t$-test for normally distributed data and the Mann-Whitney test for non-parametric data. The Kruskal-Wallis test or ANOVA was used to compare the mean values between three or more groups. A bivariate correlation analysis was performed to determine the correlations between the pairs of variables using Pearson's test and Spearman's test. All tests were considered significant if the p-value was less than 0.05. Statistical Package for the Social Sciences (SPSS), version 17.0, was used for the analyses.

\section{Ethical standards}

The study was approved by the Research Ethics Committee of MCO under resolution 010/2010. The protocol and procedures presented in the project are in accordance with the ethical standards of the responsible Committee on Human Subjects and the Helsinki Declaration of 1964, as revised in 2008. 
Results

The women had a mean age of $32.1( \pm 4.3)$ years, ranging between 19 and 40 years. In the control group, the mean age was $25.8( \pm 6.5)$ with a range from 16 to 40 years. The mean number of abortion cases was $2.8 \pm 1.0$, ranging from 2 to 7 . It was observed higher frequency of subjects in the group with 2 abortions $(47.6 \%)$, followed by the group with 3 abortions $(37.7 \%$ ) (Table 1 ).

Women with recurrent miscarriage ages were categorized into 3 groups: $\leq 30$ years, $30-35$ years, and $>35$ years. We observed a higher frequency $(11.2 \%$; $8 / 72$ ) of chromosomal abnormalities in the group of women with age between 30 and 35 years, compared to women under 30 years $(3.6 \% ; 2 / 56)$. However, no association was observed between maternal age and the frequency of chromosomal abnormalities $(\mathrm{p}=0.3)$.

Of the 151 patients with a history of recurrent miscarriage, only $46(30.5 \%)$ provided data regarding their lifestyle habits. Wich $25(54.3 \%)$ drank alcoholic beverage (once or twice per month); 35 (76\%) drank coffee and only $2(4.3 \%)$ were smokers (smoked 1 or 2 cigarettes per day). Of the 96 women in the control group, $42(43.7 \%)$ reported that they consumed alcoholic beverage (once or twice per month); 83 (86.4\%) drank coffee and 11 (11.4\%) were smokers (smoked 1 or 2 cigarettes per day). None of the habits showed a statistically significant difference when compared with the controls $(\mathrm{p}=0.15, \mathrm{p}=0.18$ and $\mathrm{p}=0.15$, respectively) (Table 2 ).

The frequency of chromosomal abnormalities was more prevalent in the women with pregnancy loss (7.3\%) than in the controls (1\%) (Table 3). An association was observed between chromosomal abnormalities and recurring losses in the first trimester $(\mathrm{OR}=7.7$; IC95\% 1.2-170.5).

Among the women with pregnancy loss, we identified 7 cases (4.7\%) of X-chromosome mosaicism: 3 (46, $\mathrm{XX} / 47, \mathrm{xxx} / 45, \mathrm{x}), 2$ (46, XX/47, xxx), 1 (46, XX / $49 \mathrm{xxxxx})$ and $1(46, \mathrm{xx} / 49, \mathrm{xxxxx} / 45, \mathrm{x}) ; 3$ cases $(2 \%)$ of reciprocal translocations: $[\mathrm{t}(11 ; 18), \mathrm{t}(2 ; 12)$ and $\mathrm{t}(11 ; 17)]$ and 1 case $(0.6 \%)$ of Robertsonian translocation $(14,21)$ (Table 3). However, no significant difference between the numerical and structural changes was found $(\mathrm{p}=0.10)$.

Table 1. Number of abortions of women with history of recurrent miscarriages

\begin{tabular}{l|cc}
\hline Number of abortions & Number of patients & $\%$ \\
\hline 2 & 72 & 47.6 \\
3 & 57 & 37.7 \\
4 & 11 & 7.2 \\
5 & 6 & 3.9 \\
6 & 4 & 2.6 \\
7 & 1 & 0.6 \\
Total & 151 & 100 \\
\hline
\end{tabular}

We found that $2.1 \%$ of the partners had chromosomal abnormalities ( 1 case of $\mathrm{X}$-chromosome mosaicism and other inversions (18) q10) and, in the controls, 1 case of $\mathrm{X}$-chromosome mosaicism was found (Table 3).

In addition, an extra G-band was detected in 5 cases in the group of women with pregnancy loss (3 cases of $9 \mathrm{qh}+$ and 2 cases of $16 \mathrm{qh}+$ ) and in 6 cases of $9 \mathrm{qh}+$ in the group of fathers. Pericentric inversion of chromosome 9 was observed in 1 woman with recurrent miscarriages and in 3 cases in the controls. This inversion was considered a normal variant in the population. One patient had a chromosome 21 with the rod increased satellite (Table 4).

Table 2. Epidemiological data of women with recurrent miscarriage and controls

\begin{tabular}{l|c|c|c}
\hline Duta & Cases & Controls & p-value \\
\hline Age (mean) & 32.1 & 25.8 & $<0.001$ \\
\hline Mean abortions & 2.8 & $1.8 \%$ & \\
Smoker & $11.4 \%$ & $4.3 \%$ & 0.1 \\
Alcoholic beverage & $54.3 \%$ & $43.7 \%$ & 0.1 \\
Coffee & $76.0 \%$ & $86.4 \%$ & 0.1 \\
Mean meals/day & 4.0 & 4.2 & NS \\
Thrombosis & 0 & 0 & \\
Use of medication (Yes) & $4.3 \%$ & $3 \%$ & NS \\
Education & & & \\
$\quad$ College & $30.4 \%$ & $9 \%$ & NS \\
High School & $69.6 \%$ & $91 \%$ & NS \\
Racial group ${ }^{\&}$ & & & \\
Whife & $17.3 \%$ & $16 \%$ & NS \\
Black & $11.0 \%$ & $27.0 \%$ & NS \\
Mulatio & $71.7 \%$ & $57.0 \%$ & NS \\
\hline
\end{tabular}

${ }^{\#}$ Live children; ${ }^{8}$ according to Krieger et al. ${ }^{23} ;$ NS: No significant.

Table 3. Chromosomal abnormalities in the group of women with recurrent miscarriages and their partners and the controls

\begin{tabular}{lccc}
\hline Individuals & Structural alterations (n) & Numerical alteration (n) & Total (\%) \\
\hline \multirow{4}{*}{ Women } & $46, x x t(11 ; 18)(q 25 ; 921)(1)$ & $46, x x / 47, x x x(2)$ & \\
& $46, x x t(11 ; 17)(1)$ & $46, x x / 47, x x x / 45, x(3)$ & \\
& $46, x x t(2 ; 12)(1)$ & $46, x x / 49, x x x x x / 45, x(1)$ & \\
Total & $45, x x r o b(14 ; 21)(q 10 q 10)(1)$ & $46, x x / 49, x x x x x(1)$ & \\
Controls & $4(2.6 \%)$ & $7(4.7 \%)$ & $11(7.3 \%)$ \\
Men & - & $46, x x / 47, x x x(1)$ & $1(1 \%)$ \\
\hline
\end{tabular}

Table 4. Normal variations in the structure of chromosomes in cases and controls

\begin{tabular}{|c|c|c|c|}
\hline Individuals & Normal variants & $n$ & Total (\%) \\
\hline \multirow{4}{*}{ Women } & $46, X X$ inv (9p) & 1 & \\
\hline & 46,XX, 21pstk+ & 1 & \\
\hline & $46, x x, 9 q h+$ & 3 & \\
\hline & $46, X X, 16 q h+$ & 2 & $7(4.6)$ \\
\hline Controls & $46, X X \operatorname{inv}(9 p)$ & 3 & $3(3.0)$ \\
\hline Men & 46xy9gh+ & 6 & $6(6.4)$ \\
\hline
\end{tabular}




\section{Discussion}

In the present study, we found significant differences for chromosomal aberrations (CA) when comparing 151 women with abortions $(7.3 \%)$ to 100 controls (1\%). This frequency of CA was similar to that observed in other reports $^{8,12}$ (8.9 and $9.3 \%$, respectively). However, other studies reported lower frequencies of $\mathrm{CA}^{7,13}$ (3.8 and $4.9 \%$, respectively). A review of the literature showed that, in 4.7 to $12.5 \%$ of couples with at least 2 miscarriages, 1 partner carries a chromosomal alteration ${ }^{4,8,14,15}$. Many studies attribute this variability to differences in the sample size and variations in the criteria for selection of the individuals, such as the number of abortions and the exclusion of those with defined etiology. Our findings could be due to our stringent case selection of women with early abortions with unidentified cause.

Chromosomal abnormalities were found in 11 women with pregnancy loss, including mosaicism in the $\mathrm{X}$-chromosome in 7 cases $(63.7 \%)$, reciprocal translocations in 3 cases $(27.3 \%)$ and Robertsonian translocation in 1 case $(9 \%)$. The frequency of $\mathrm{X}$-chromosome mosaicism was higher than that found in previous reports, where it has been reported to be between $0-30 \%$ of the cases.

However, similar results were found by Kiss et al. ${ }^{12}$ and $\mathrm{Pal}$ et al. ${ }^{8}$, who reported $\mathrm{X}$-chromosome mosaicism in 50 and $48 \%$ of the cases, respectively. This finding is likely related to the type of sample selected and the number of metaphases analyzed. In our study, we analyzed 30 cells, but most other studies have investigated 15 to 20 cells. According to the literature, the greater the number of metaphases analyzed, the greater the chance of detecting mosaicism of lesser degree.

It has been related that approximately $3 \%$ of infertile males and $5-10 \%$ of those with oligospermia or azoospermia had mosaic Klinefelter syndrome ${ }^{16}$.

In the present study, we found 4 cases of translocations in women with recurrent miscarriages: $\mathrm{t}(11 ; 18), \mathrm{t}(2 ; 12)$, $\mathrm{t}(11 ; 17)$ and 1 Robertsonian translocation $(14 ; 21)$. The translocations were more common in women $(2.6 \%)$ compared to men (no cases), which has also been reported by other authors. According to some authors, as male carriers of translocations have reduced fertility, chromosomal abnormalities in the female partner are a more common finding in couples with recurrent miscarriages ${ }^{8}$. The significant increase in reciprocal translocation in couples with reproductive failure is an expected finding because the carriers of reciprocal translocation have a significantly increased risk of chromosomal imbalance (partial chromosomal duplication/deficiency) during gametogenesis due to unequal meiotic segregation of the balanced translocation ${ }^{13,17,18}$.
It has been reported that the crossing over that occurs during meiotic division may lead to deletion or duplication of a chromosome segment in pericentric inversion. One case of pericentric inversion (in chromosome 18) was found in 1 male patient. The length of the inverted segment of carrier patients seems to be a decisive factor for determining the effects of a pericentric inversion in the progeny. Indeed, genetically unbalanced gametes have a greater chance of arising from a large rather than a small inversion in the meiotic loop ${ }^{19}$.

The most frequent pericentric inversion in the general human population is inv (9). This inversion is usually a normal polymorphism; however, its clinical consequences remain unclear ${ }^{20,21}$. In addition, the additional $\mathrm{G}(+)$ band in the cases of $9 \mathrm{qh}+$ and $16 \mathrm{qh}+$ is not believed to be an etiological cause of abortion because this band is in the heterochromatin blocks, which contain no active genes ${ }^{13}$.

The frequency of chromosomal abnormalities was higher in women with recurrent miscarriages (7.3\%) than in men $(2.1 \%)$, but without significant difference. The major chromosomal abnormalities found were $\mathrm{X}$-chromosome mosaicism (4.7\%), followed by reciprocal translocations (2\%).

An association was observed between chromosomal abnormalities and recurring abortions in the first trimester $(\mathrm{OR}=7.7$; IC95\% 1.2-170.5) in the group of women included. These data support the statement that chromosomal studies in couples with recurrent abortion are an important and necessary part of the etiological investigations. Some studies have been performed in other regions of Brazil, but this is the first in this part of the country.

Chromosome abnormalities are identified in approximately half of all first trimester spontaneous abortions. The estimate of frequency of second trimester chromosomal abnormalities is $15 \%^{22,23}$. In an attempt to obtain a homogeneous sample, we included in our study only idiopathic recurrent first trimester abortions, which reduced the sample size, preventing statistical association with covariates such as smoking, alcohol and coffee consumption.

\section{Acknowledgements}

To the Conselho Nacional de Desenvolvimento Científico e Tecnológico (CNPq), contract grant number: 620219/2008-4, and Fundação Oswaldo Cruz (FIOCRUZ)/ Brazilian Ministry of Health. We are especially grateful to the Ambulatory of Genetics of University Hospital Professor Edgard Santos, that helped us in the recruitment of women of group case. 
1. Roman E. Fetal loss rates and their relation to pregnancy order. J Epidemiol Community Health. 1984;38(1):29-35.

2. Rai R, Regan L. Recurrent miscarriage. Lancet. 2006;368(9535):601-1 1.

3. Kuo PL, Guo HR. Mechanism of recurrent spontaneous abortions in women with mosaicism of X-chromosome aneuploidies. Fertil Steril. 2004;82(6): 1594-601.

4. Carp H, Toder V, Aviram A, Daniely M, Mashiach S, Barkai G. Karyotype of the abortus in recurrent miscarriage. Fertil Steril. $2001 ; 75(4): 678-82$

5. Hogge WA, Byrnes AL, Lanasa MC, Surti U. The clinical use of karyotyping spontaneous abortions. Am J Obstet Gynecol. 2003; 189(2):397-400.

6. De Braekeleer M, Dao TN. Cytogenetic studies in couples experiencing repeated pregnancy losses. Hum Reprod. 1990;5(5):519-28.

7. Ozawa N, Maruyama T, Nagashima T, Ono M, Arase T, Ishimoto H, et al. Pregnancy outcomes of reciprocal translocation carriers who have a history of repeated pregnancy loss. Fertil Steril. 2008;90(4):1301-4

8. Pal S, Ma SO, Norhasimah M, Suhaida MA, Siti Mariam I, Ankathil $R$, et al. Chromosomal abnormalities and reproductive outcome in Malaysian couples with miscarriages. Singapore Med J. 2009;50(10):1008-12.

9. Hirshfeld-Cytron J, Sugiura-Ogasawara $M$, Stephenson MD. Management of recurrent pregnancy loss associated with a parental carrier of a reciprocal translocation: a systematic review. Semin Reprod Med. $2011 ; 29(6): 470-81$.

10. Sugiura-Ogasawara M, Aoki K, Fujii T, Fujita T, Kawaguchi R, Maruyama T, et al. Subsequent pregnancy outcomes in recurrent miscarriage patients with a paternal or maternal carrier of a structural chromosome rearrangement. J Hum Genet. 2008;53(7):622-8.

11. Stephenson MD. Frequency of factors associated with habitual abortion in 197 couples. Fertil Steril. 1996;66(1):24-9.

12. Kiss A, Rosa RFM, Dibi RP, Zen PRG, Pfeil JN, Graziadio C, et al. [Chromosomal abnormalities in couples with history of recurrent abortion]. Rev Bras Ginecol Obstet. 2009;31(2):68-74.
13. Celep F, Karagüzel A, Ozeren M, Bozkaya $H$. The frequency of chromosomal abnormalities in patients with reproductive failure. Eur J Obstet Gynecol Reprod Biol. 2006; 127(1):106-9.

14. Kochhar PK, Ghosh P. Reproductive outcome of couples with recurrent miscarriage and balanced chromosomal abnormalities. J Obstet Gynaecol Res. 2013;39(1):113-20.

15. Van den Berg MM, van Maarle $M C$, van Wely $M$, Goddijn $M$. Genetics of early miscarriage. Biochim Biophys Acta. 2012;1822(12):1951-9

16. Abdel-Razic MM, Abdel-Hamid IA, Elsobky E, El-Dahtory F. Further evidence of the clinical, hormonal, and genetic heterogeneity of Klinefelter Syndrome: a study of 216 infertile Egyptian patients. J Androl. 2012;33(3):441-8.

17. Fryns JP, Van Buggenhout $G$. Structural chromosome rearrangements in couples with recurrent fetal wastage. Eur J Obstet Gynecol Reprod Biol. 1998;81(2):171-6.

18. Panasiuk B, Danik J, Lurie IW, Stasiewicz-Jarocka B, Le囚niewicz R, Sawicka $A$, et al. Reciprocal chromosome translocations involving short arm of chromosome 9 as a risk factor of unfavorable pregnancy outcomes after meiotic malsegregation 2:2. Adv Med Sci. 2009;54(2):203-10.

19. Fauth C, Bartels I, Haaf T, Speicher MR. Additional dark G-band in the p-arm of chromosome 19 due to a paracentric inversion with a breakpoint in the pericentromeric heterochromatin. Am J Med Genet. 2001;103(2):160-2.

20. Amiel A, Sardos-Albertini F, Fejgin MD, Sharony R, Diukman R, Bartoov B. Interchromosomal effect leading to an increase in aneuploidy in sperm nuclei in a man heterozygous for pericentric inversion (inv 9) and C-heterochromatin. J Hum Genet. 2001;46(5):245-50.

21. Dana $M$, Stoian V. Association of pericentric inversion of chromosome 9 and infertility in romanian population. Maedica (Buchar). 2012;7(1):25-9.

22. Simpson JL. Causes of fetal wastage. Clin Obstet Gynecol. 2007;50(1): 10-30.

23. Krieger $\mathrm{H}$, Morton NE, Mi MP, Azevêdo ES, Freire-Maia N, Yasuda N. Racial admixture in north-eastern Brazil. Ann Hum Genet. 1965;29(2): 113-25. 